\title{
Communication
}

\author{
[Comunicação]
}

\section{Identification of microchips through diagnostic imaging helps to determine the longevity of the golden lancehead (Bothrops insularis) in captivity}

\author{
[Identificação de microchips por meio de diagnóstico por imagem \\ auxilia a determinar a longevidade da jararaca-ilhoa \\ (Bothrops insularis) em cativeiro] \\ V.C. Garcia $^{1,2}$, S.M. Unruh ${ }^{3}$, S.M. Almeida-Santos ${ }^{2,3}$ \\ ${ }^{1}$ Aluno de pós-graduação - Programa de Anatomia dos Animais Domésticos e Silvestres - Faculdade \\ de Medicina Veterinária e Zootecnia - Universidade de São Paulo - São Paulo, SP \\ ${ }^{2}$ Laboratório de Ecologia e Evolução - Instituto Butantan - São Paulo, SP \\ ${ }^{3}$ Faculdade de Medicina Veterinária e Zootecnia - Universidade de São Paulo - São Paulo, SP
}

The golden lancehead Bothrops insularis is endemic to the Queimada Grande Island, located $32 \mathrm{~km}$ from the city of Itanhaém, state of São Paulo, southeastern Brazil (Marques et al., 2012). This species was intensively collected on the Queimada Grande Island between 1914 and 1924, and during this period, about 450 specimens were incorporated into the herpetological collection and laboratories of the Butantan Institute. These specimens were brought to the institute by lighthouse keepers who lived on the island and by the institute's researcher Afrânio do Amaral (Duarte et al., 1995).

No further expeditions occurred for over 20 years until the institute's researcher, Dr. Alphonse Richard Hoge, visited the island between 1947 and 1970 (Hoge et al., 1959). The island was visited again for research purposes only fourteen years later, during the 1980s (Kasperoviczus and Almeida-Santos, 2012). At the beginning of the $21^{\text {st }}$ century, Professor Marcio Martins (University of São Paulo) obtained financial support from the Boticário Foundation for Nature Protection, and the snakes found on the island began to be marked with transponders (microchips) allowing advances in long-term population studies (Marques et al., 2012). From 2007 to 2009, several expeditions were carried out by researcher Otavio Marques

Recebido em 2 de dezembro de 2018

Aceito em 28 de junho de 2019

E-mail: vivianecgarcia@hotmail.com
(Butantan Institute) funded by FAPESP (São Paulo Research Foundation).

These expeditions enabled the collection of about 20 individuals of $B$. insularis. These individuals were brought to the Laboratory of Ecology and Evolution of the Butantan Institute, and since then they have been kept in captivity for biological and reproductive studies, as well as for ex situ conservation (IBAMA License no. 25.650-1; Kasperoviczus and Almeida-Santos, 2012). During the expeditions, snakes were measured, weighed, sexed, palpated for the presence of follicles or developing embryos, and marked with implantable microchips.

Diagnostic imaging has been of great importance in reptile medicine. A precise physical exam is difficult to perform, but radiography and ultrasonography have allowed more detailed studies aiming at a better knowledge of organs, bones, and tissues of several snake species (Garcia et al., 2015). This work reports the use of diagnostic imaging (radiography and ultrasound) to identify the presence of microchips and, consequently, estimate the age of a captive $B$. insularis.

In July 2003, researchers from the Butantan Institute visited the Queimada Grande Island to collect biological data and ascertain environmental conditions (Duarte et al., 2005). 
In this expedition, researchers captured a female $B$. insularis containing eight ovarian follicles. This specimen measured $700 \mathrm{~mm}$ snout-vent length (SVL), 100mm tail length (TL), and weighed 140g (Table 1). After examination, the animal was implanted with a microchip (identification number 0001268792) and released at the capture site. In 2009, about 20 individuals of $B$. insularis were collected (with permission from SISBIO and IBAMA) and brought to the Laboratory of Ecology and Evolution of the Butantan Institute (São Paulo, Brazil).

Table 1. Biological data of an individual of Bothrops insularis (number 13) observed between 2003 and 2018

\begin{tabular}{cccc}
\hline Date & $\begin{array}{c}\text { Snout-vent length+tail } \\
\text { length }(\mathrm{mm})\end{array}$ & Body mass $(\mathrm{g})$ & Age (years) \\
\hline July 2003 & $700+100$ & 140 & $\cong 3-4$ \\
October 2009 & $818+108$ & 275 & $\cong 9-10$ \\
February 2018 & $1000+120$ & 579 & $\cong 18-19$ \\
\hline
\end{tabular}

Once in the lab, snakes were quarantined and implanted with subcutaneous microchips. In 2015, some captive snakes received new microchips because the old ones were no longer being detected with the universal microchip reader (Global Mark). In December 2017, radiographic and ultrasonographic examinations were performed on the snakes to investigate their physical conditions. We found that an individual of $B$. insularis (number 13) had three microchips. Imaging procedures were performed at the
Diagnostic Imaging Service of the School of Veterinary Medicine and Animal Science of the University of São Paulo. Microchip 1 (0001268792) was read using a pocket reader (Trovan, Ltd.), and microchip 3 (FDXB982000364507461) was read using a Global Mark reader. Microchip 2 was not readable and was identified by retrieving its information from the animal's record database (Table 2).

Table 2. Location of the microchips in the snake Bothrops insularis (number 13)

\begin{tabular}{ccc}
\hline Microchip & Microchip number & Location/Radiography \\
\hline 1 & 0001268792 & $\begin{array}{c}\text { Left side }-380 \mathrm{~mm} \text { above the cloaca } \\
\text { (ventral }- \text { midbody) }\end{array}$ \\
2 & 6361AD7 & $\begin{array}{c}\text { Left side }-200 \text { mm above the cloaca } \\
\text { (dorsal }- \text { caudal third) }\end{array}$ \\
3 & FDXB982000364507461 & $\begin{array}{c}\text { Right side }-90 \text { mm above the cloaca } \\
\text { (dorsal }- \text { caudal third) }\end{array}$ \\
\hline
\end{tabular}

Through radiography, we identified subcutaneous structures compatible with microchips. These structures were located in the ventral region of the mid-body and the dorsal region of the caudal third of the snake (Figure 1A). Through ultrasonography, the microchips were visualized as hyperechogenic subcutaneous structures located in the coelomic cavity (Figure. 1B) and ventral to the vertebral column (Figure. 1C-D). From these data, we conclude that this individual was the same one collected and marked on the island in July 2003. When this individual arrived at our laboratory in October 2009, it had $818 \mathrm{~mm} \mathrm{SVL,} 108 \mathrm{~mm}$ TL and weighed $275 \mathrm{~g}$.
In February 2018, the snake measured $1000 \mathrm{~mm}$ SVL, $120 \mathrm{~mm}$ TL, and weighed $579 \mathrm{~g}$ (Table 1). The SVL of this individual in 2003 was similar to that observed in captive $B$. insularis at 3-4 years old (Araoz et al., 2018). According to Mansano et al. (2013), radiography allows us to find the correct location of the implanted microchips. Thus, diagnostic imaging helped us to identify the microchips in an individual of $B$. insularis and, consequently, estimate its age at about 18-19 years, suggesting a generation of old snakes. 

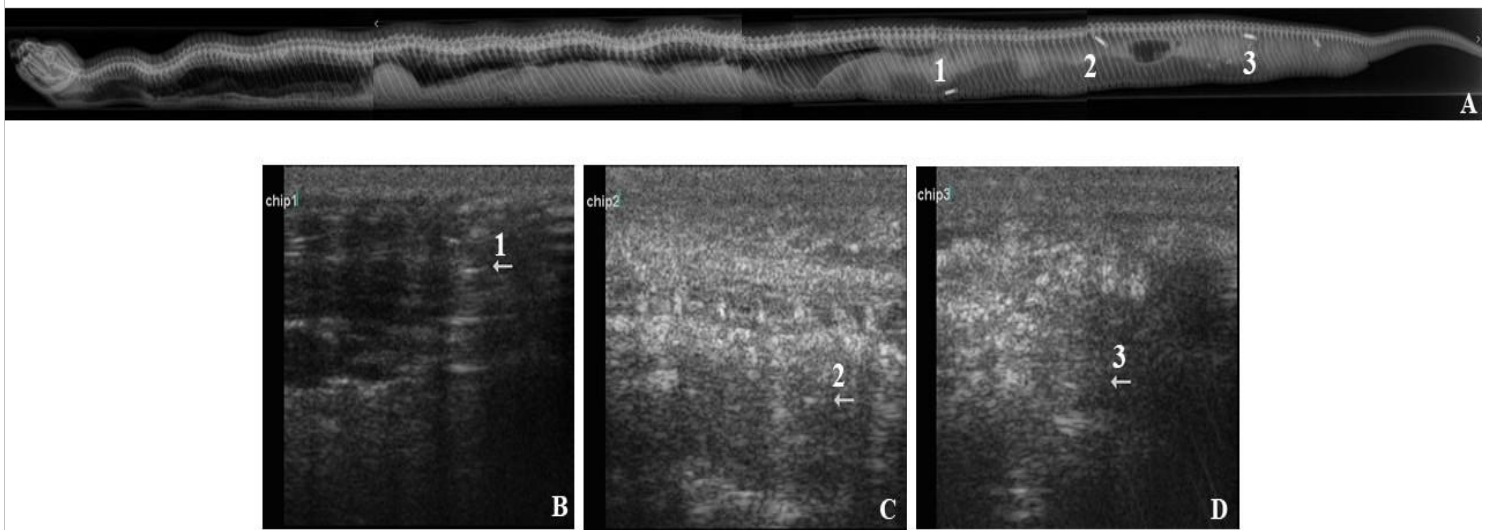

Figure 1. A- Radiographic evaluation of an individual of Bothrops insularis (number 13) performed in February 2018. The radiographic image shows structures compatible with microchips in the ventral region of the mid-body (microchip 1) and the dorsal region of the caudal third of the snake (microchips 2 and 3). B-D - Ultrasound evaluation showing subcutaneous hyperechogenic structures measuring $1 \mathrm{~cm}$ in the (B) coelomic cavity (microchip 1) and (C-D) ventral to the vertebral column (microchips 2 and 3). Images provided by the Diagnostic Imaging Service of the School of Veterinary Medicine and Animal Science of the University of São Paulo (FMVZ - USP).

Keywords: snake, radiology, ultrasound, body size, age

\section{RESUMO}

As serpentes vindas da natureza e encaminhadas para centros de reabilitação ou de pesquisa têm uma idade incerta. Na natureza, esses animais, muitas vezes atingem um tamanho corpóreo menor do que os indivíduos cativos devido a uma menor frequência de alimentação. Assim, a idade de uma cobra recémchegada da natureza é geralmente estimada com base em seu tamanho corpóreo, o qual é comparado com dados em cativeiro. A utilização dos meios de diagnóstico por imagem tem auxiliado a medicina na análise das serpentes em cativeiro, mediante avaliação da estrutura óssea, dos órgãos e de alterações. Este trabalho relata o uso de diagnóstico por imagem (radiografia e ultrassonografia) para identificar a presença de microchips e, consequentemente, estimar a idade de uma Bothrops insularis em cativeiro.

Palavras-chave: serpente, radiologia, ultrassom, tamanho corpóreo, idade

\section{ACKNOWLEDGMENTS}

This study was financed in part by the Coordenação de Aperfeiçoamento de Pessoal de Nível Superior - Brasil (CAPES). We thank Marcelo Ribeiro Duarte for providing the 2003 collection data, Adriano Fellone and Kelly Kishi for their assistance in the laboratory, Marcio Candido for assistance with radiographic images, and Henrique Braz for reviewing the language of the manuscript. This study was conducted at the Laboratory of Ecology and Evolution, Butantan Institute, São Paulo, Brazil, under the approval of the institute's Animal Ethics Committee (approval number 2732151216).

\section{REFERENCES}

ARAOZ, A.C.C.; GARCIA, V.C.; PINTO, C.M.; ALMEIDA-SANTOS, S.M. Deworming protocols of island snakes kept in capitivity at the Butantan Institute. Arch. Vet. Sci., v.23, p.35-42, 2018.

DUARTE, M.R.; ONOFRIO, V.C.; BATESTI, D. M. B. Bothrops insularis, golden lancehead (Serpentes: Viperidae): a heavily ectoparasitized pit viper population. Mem. Inst. Butantan, v. 62, p. $84,2005$. 
DUARTE, M.R.; PUORTO, G.; FRANCO, F.L. A biological survey of the pitviper Bothrops insularis Amaral (Serpentes, Viperidae): an endemic and threatened offshore island snake of southeastern Brazil. Stud. Neotrop. Fauna Environ., v.30, p.1-13, 1995.

GARCIA, V.C.; VAC, M.H.; BADIGLIAN, L.; SANTOS, S.M.A. Avaliação ultrassonográfica do aparelho reprodutor em serpentes vivíparas da família Boidae. Pesqui. Vet. Bras., v.35, p.311$318,2015$.

HOGE, A.R.; BELLUOMINI, H.E.; SCHREIBER, G.; PENHA, A.M. Sexual abnormalities in Bothrops insularis (Amaral, 1921). Mem. Inst. Butantan, v.29, p.17-88, 1959.

KASPEROVICZUS, K.N.; ALMEIDASANTOS, S.M. Instituto Butantan e a JararacaIlhoa: cem anos de história, mitos e ciência. $\mathrm{Cad}$. Hist. Ciênc., v.8, p.255-269, 2012.
MANSANO, C.F.M.; STÉFANI, M.V.; PEREIRA, M.M.; MACENTE, B.I. Avaliação de diferentes locais de implante de microchip para identificação eletrônica de reprodutores de rãtouro e sua validação por meio da análise de imagem. Rev. Bras. Reprod. Anim., v.37, p.295297, 2013.

MARQUES, O.A.V.; MARTINS, M.; DEVELEY, P.F. et al. The golden lancehead Bothrops insularis (Serpentes: Viperidae) relies on two seasonally plentiful bird species visiting its island habitat. J. Nat. Hist., v.46, p.885-895, 2012. 